\title{
ANÁLISE EMPÍRICA DOS INCIDENTES DE RESOLUÇÃO DE DEMANDAS REPETITIVAS NOS JUIZADOS ESPECIAIS
}

Camilo Zufelatoi

Gustavo Tavares de Oliveira Borgesii

Fernando Antônio Oliveiraiii

\section{RESUMO}

Este artigo objetiva analisar os dados empíricos coletados pelo Observatório Brasileiro de IRDRs, desde a vigência do CPC de 2015 até o dia 15 de junho de 2018, especificamente quanto aos incidentes suscitados que possuem expressa menção aos Juizados Especiais, a fim de compreender e constatar como é a aplicação do novo instituto criado pelo CPC de 2015 a partir de processos que tramitaram no âmbito dos Juizados Especiais. Alguns aspectos da doutrina serão levantados para elucidar a interação entre os dois objetos de estudo, como a independência jurisdicional dos juízes dos Juizados Especiais em relação aos Tribunais e a natureza jurídica do IRDR, bem como as fundamentações utilizadas nos julgados, os quais possuem resultados divergentes.

PALAVRAS-CHAVE: IRDR; juizados especiais; precedentes vinculantes; demandas repetitivas.

'Universidade de São Paulo, Faculdade de Direito, Ribeirão Preto, SP, Brasil, ORCID; i'Universidade de São Paulo, Faculdade de Direito, Ribeirão Preto, SP, Brasil, ORCID; iiiUniversidade de São Paulo, Faculdade de Direito, Ribeirão Preto, SP, Brasil, $\underline{\text { ORCID. }}$ 


\title{
EMPIRICAL ANALYSIS OF THE INCIDENTS OF RESOLUTION OF REPETITIVE DEMANDS IN THE SMALL CLAIMS COURTS
}

Camilo Zufelato Gustavo Tavares de Oliveira Borges Fernando Antônio Oliveira

\begin{abstract}
This article aims to analyse the data collected by the Brazilian Observatory of IRDR, since the actual Code of Civil Procedure validity until June 15 2018, specifically related to the raised incidents that have express mention to the Small Claims Courts, in order to understand and verify how is the application of the 2015 Code of Civil Procedure's new institute on the Small Claims Courts' trials. Some legal doctrine aspects are also discussed to understand how is the interaction of both study objects, like the jurisdictional independence of Small Claims Courts' judges from the regular Courts and the IRDR legal nature, as well as the grounds of the judicial decisions, which are divergent.
\end{abstract}

KEYWORDS: IRDR; small claims courts; binding precedents; repetitive demands. 


\section{INTRODUÇÃO}

O Incidente de Resolução de Demandas Repetitivas (IRDR), criado no CPC de 2015 com o objetivo de fixar tese vinculante quanto a questões de direito das demandas repetitivas, trouxe diversas discussões doutrinárias. Isso em razão das dúvidas que pairam sobre seus dispositivos legais, os quais foram objeto de diversas alterações no processo legislativo, que resultaram em vasto debate na doutrina e em sua aplicação pelos Tribunais brasileiros.

Um dos aspectos acrescentados nos debates legislativos é a expressa determinação quanto à aplicação da tese vinculante inclusive nos processos que tramitam perante os Juizados Especiais respectivos do Tribunal julgador. A parte final do inciso I do art. 985, CPC, foi acrescentada por provocação da Associação dos Juízes Federais do Brasil (AJUFE) a partir do Substitutivo aprovado pela Câmara dos Deputados e recebido pelo Senado Federal (Mendes, 2017, pp. 159161). Apesar da vinculação ser expressa no texto legal, há doutrina (Nery Jr. \& Nery, 2015, p. 1996) contrária à aplicação do precedente vinculante no âmbito dos Juizados Especiais, sob o fundamento de independência jurisdicional dos juízes dos Juizados Especiais em relação ao que decidido pelo Tribunal.

Para além da aplicação do precedente vinculante também no âmbito dos Juizados Especiais, Aluisio Mendes (2017, p. 161) menciona que a proposta da AJUFE incluía disposição no sentido de que o IRDR pudesse ser suscitado, admitido e julgado pelos órgãos dos Juizados Especiais responsáveis pela uniformização jurisprudencial, o que porém não teve expresso acolhimento no texto final. A justificativa da sugestão assentava-se no comando constitucional do art. 98, I, parte final, que institui complexo recursal para os Juizados Especiais e restringe o julgamento dos recursos dentro do próprio sistema criado pela legislação infraconstitucional.

Todavia, a possibilidade de julgamento do IRDR pelos órgãos dos Juizados Especiais também é controvertida na doutrina. Aponta-se que a competência prevista pelo CPC para o deslinde do incidente é exclusiva do Tribunal (Monnerat, 2017, p. 501), o que não abrangeria as turmas de uniformização dos Juizados 
Especiais. Considerando ainda as características dos Juizados Especiais, que se destinam ao adequado tratamento da litigiosidade contida - esta relativa aos conflitos não levados ao Poder Judiciário em razão das barreiras encontradas, como custas judiciais, burocracia, formalidade e tempo excessivos (Watanabe, 1985, p. 2) -, o processamento do IRDR poderia se revelar incompatível com a proposta de funcionamento dos Juizados Especiais. Isso em razão de eles serem fundados em processo diferenciado (Dinamarco, 2005, p. 771), marcado pela técnica processual simplificada, oral, célere, informal e econômica, que não se compatibilizaria com a complexidade da matéria e do rito do IRDR.

Outro aspecto central para a compreensão desta pesquisa é a presença ou não do requisito de causa pendentel, o que se relaciona principalmente à interpretação do artigo 978, parágrafo único, do CPC, o qual seria um comando para que o Tribunal julgue também o caso em que foi suscitado o IRDR. Assim, somente seria possível suscitar o incidente a partir de recurso, remessa necessária ou ação de competência originária do Tribunal pendentes de julgamento (Cavalcanti, 2016, pp. 223-232). Os processos dos Juizados Especiais não seriam suscetíveis de IRDR no Tribunal, portanto, uma vez que os seus recursos são julgados por órgãos dos próprios Juizados Especiais, não chegam à apreciação pelo Tribunal.

Parte oposta da doutrina se inclina à interpretação desse dispositivo como regra de prevenção para julgamento do recurso no processo em que o IRDR fora suscitado, de modo a não ser necessária a suscitação do incidente em causa pendente de julgamento em segunda instância. Isso considerando a natureza objetivada do IRDR pela existência da cisão decisória (Temer, 2018, pp. 113-120), sendo apenas a questão de direito apreciada pelo órgão do Tribunal, sem julgar o processo de onde o incidente foi suscitado. Dessa forma, a competência dos Juizados Especiais não é dispensada: o juiz do processo originário julgará a causa aplicando a tese vinculante fixada (Marinoni, 2016, p. 71).

\footnotetext{
1 Para um estudo mais aprofundado sobre todas as facetas da causa pendente, conferir o estudo de Fernando A. Oliveira (2019, pp. 175-186).
} 
É a partir dessa perspectiva que este estudo objetiva a análise da relação entre o IRDR e os Juizados Especiais, utilizando-se dos dados do Observatório Brasileiro de IRDRs2, cuja base de dados aqui utilizada de parâmetro contabiliza 677 incidentes suscitados nos Tribunais de Justiça e nos Tribunais Regionais Federais, no período compreendido desde a vigência do CPC atual até 15 de junho de 2018. Esses dados deram suporte ao I Relatório de Pesquisa do Observatório, o qual está disponível no endereço eletrônico do grupo de estudos3, local onde se encontra também a planilha gerada com todas as informações individuais dos incidentes analisados.

Em específico, este trabalho utiliza dados empíricos da mencionada base do Observatório Brasileiro de IRDRs, com filtro voltado à seleção dos incidentes em que há qualquer tipo de menção expressa aos Juizados Especiais. A partir desse filtro, pretende-se a análise de como a suscitação de IRDR relacionado aos Juizados é enfrentada pelos Tribunais brasileiros, considerando principalmente as razões trazidas para enfrentar o (des)cabimento de IRDR a partir de processos que tramitam nos Juizados Especiais. O estudo será pontuando com comentários doutrinários sobre a questão e notas críticas aos resultados encontrados pela pesquisa, tendo em vista aspectos relevantes quanto à (in)compatibilidade do IRDR com os propósitos dos Juizados Especiais no tratamento da litigiosidade contida.

\section{IDENTIFICAÇÃO DOS IRDRs SUSCITADOS QUE SE RELACIONAM AOS JUIZADOS ESPECIAIS}

A base de dados do Observatório Brasileiro de IRDRs, conforme atualização até 15 de junho de 2018, conta com 677 incidentes com juízo de admissibilidade

\footnotetext{
2 Trata-se de grupo de pesquisa, cadastrado na plataforma do CNPq, que se destina à coleta de dados dos incidentes suscitados nos Tribunais brasileiros e ao fomento de pesquisas relacionadas ao tema, realizando lançamentos periódicos de relatórios de análise dos dados coletados, os quais podem ser acessados no endereço eletrônico do Observatório <observatorioirdr.direitorp.usp.br>. O I Relatório conta com dados dos incidentes suscitados desde a vigência do CPC de 2015 até o dia 15 de junho de 2018 , os quais serão aqui analisados.

${ }^{3}$ Disponível em http://observatorioirdr.direitorp.usp.br, acesso em agosto de 2020.
} 
realizado, desde a entrada em vigor do CPC de 2015. Foi aplicado formulário padronizado às decisões de admissibilidade e de mérito desses IRDRs, os quais podem ser conferidos no endereço eletrônico do grupo de pesquisa, assim como a descrição detalhada da metodologia empregada.

A partir dos dados obtidos neste recorte temporal mencionado, buscou-se selecionar apenas aqueles IRDRs que fazem expressa menção à expressão "Juizados Especiais" ou que tenha envolvido algum dos seus órgãos, como turma recursal e turma de uniformização. Assim, dentre o universo de 677 incidentes suscitados identificados pelo Observatório, foram filtrados 51 que se enquadram nessa situação, representando cerca de 7,53\% do total.

Desse conjunto, entretanto, nem todos os 51 incidentes foram suscitados a partir de processo que tramitava perante os Juizados Especiais. Na verdade, 16 deles foram suscitados a partir de processos que tramitavam fora dos Juizados (Tribunal), tanto em primeira quanto em segunda instância, enquanto 35 foram suscitados a partir de processos dos Juizados Especiais, revelando o seguinte gráfico:

\section{Gráfico 1}

O IRDR foi suscitado a partir de processo que tramita nos Juizados Especiais?

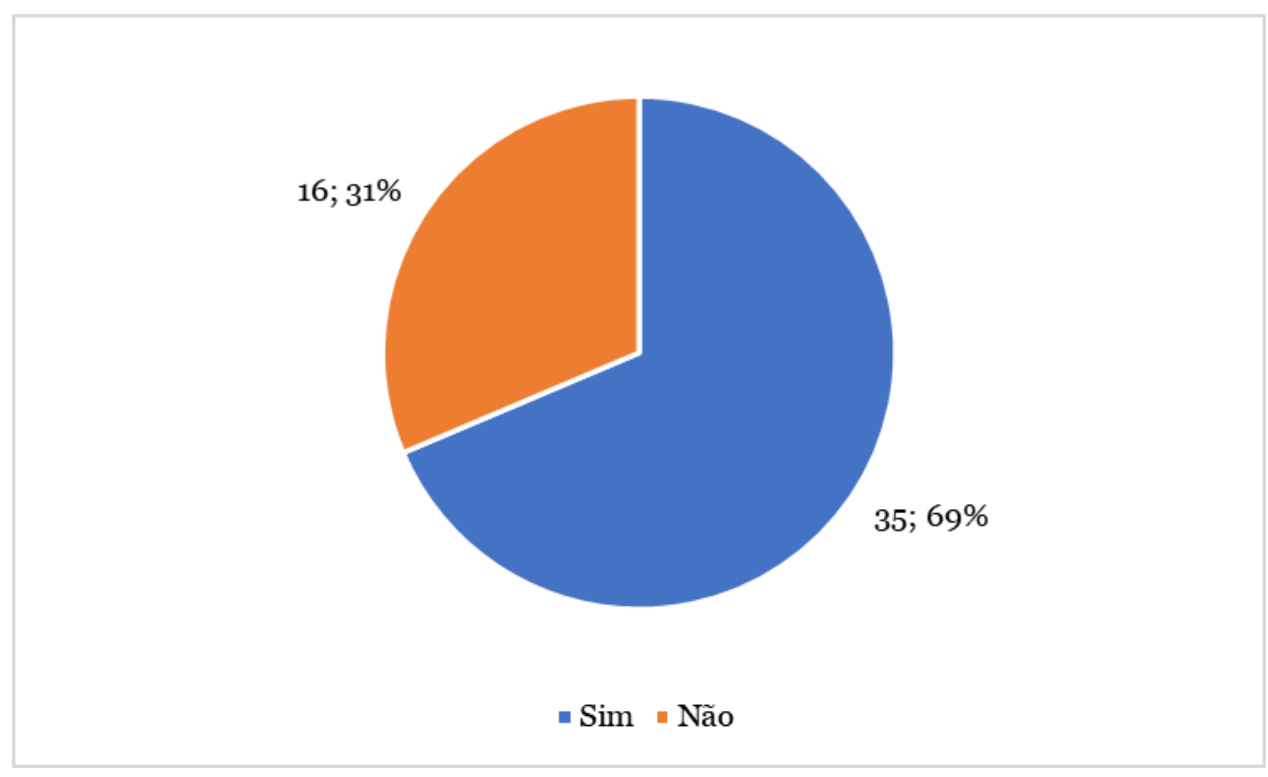

Fonte: Observatório Brasileiro de IRDRs. 
Dentre os incidentes suscitados a partir de processo que tramitavam no Tribunal, são 14 IRDRs que mencionam diretamente os Juizados Especiais, tendo sido suscitados a partir de conflito de competência, processos do Tribunal, portanto, a fim de dirimir controvérsia quanto à possibilidade de propositura de uma ação perante o Juizado Especial, em atenção à necessidade de adequação da lide à estrutura dos Juizados conforme suas regras de competência.

Sobre os outros dois incidentes encontrados e referentes a este conjunto de incidentes suscitados a partir de processos estranhos ao Juizado, anota-se que ambos são do TJTO4, e a menção sobre Juizado neles se refere à inclusão dos processos que tramitam nos Juizados Especiais na análise do requisito da efetiva repetição da questão de direito5, além dos que também tramitam perante o Tribunal. Ambas as análises foram feitas com base em dados: no IRDR $\mathrm{n}^{\circ}$ 0009560-46.2017.8.27.0000, foram considerados suficientes 1.019 processos que tramitam nos Juizados Especiais e "dezenas de outros nas varas cíveis"; no IRDR $\mathrm{n}^{\circ}$ 0020822-27.2016.8.27.0000 bastaram 12 processos das varas e dos Juizados Especiais para a incidência do requisito.

Sendo 16 IRDRs suscitados em processos dos Tribunais, restam 35 IRDRs que foram suscitados em processos que tramitam nos Juizados Especiais. Desses incidentes, apenas dois foram julgados pelos próprios órgãos dos Juizados Especiais, sendo todas essas duas ocorrências no Espírito Santo. Com efeito, a Turma de Uniformização de Interpretação de Lei dos Juizados Especiais Cíveis do Espírito Santo julgou os IRDRs de $n^{\circ}$ 039/2016 e $n^{\circ}$ 040/2016 dentro do recorte temporal estabelecido, os quais serão explorados adiante.

Os outros 33 incidentes foram julgados pelos Tribunais e em seus respectivos órgãos competentes para processamento do IRDR, o que representa cerca de 4,87\% da amostra total do Observatório, de 677 incidentes suscitados. Como se vê, apesar de os Juizados Especiais serem ambiente propício para a

\footnotetext{
${ }^{4}$ São os IRDRs do TJTO de n 0009560-46.2017.8.27.0000 e n 0020822-27.2016.8.27.0000.

${ }^{5} \mathrm{O}$ artigo 976, I, do CPC coloca como requisito para a formação de um IRDR, a efetiva repetição de questão unicamente de direito, um conceito aberto, o qual não traz parâmetros objetivos de aferição. A flexibilidade permite que o julgador balize a análise do requisito casuisticamente e, em razão disso, há diferentes critérios utilizados para a caracterização do requisito.
} 
existência de grande parte das demandas repetitivas (Koehler, 2014, p. 500), a sua representação na totalidade dos incidentes suscitados é bastante baixa. Os dados, até então, são contrários ao que parte da doutrina (Mendes \& Romano Neto, 2015, p. 302) diz a respeito do considerável aumento de acervo processual dos Tribunais caso admita-se neles julgamento de IRDR proveniente dos Juizados Especiais também argumento utilizado pelos autores contra o julgamento do IRDR proveniente dos Juizados Especiais pelos Tribunais.

\section{CARACTERÍSTICAS GERAIS DOS INCIDENTES SUSCITADOS REFERENTES AOS JUIZADOS ESPECIAIS}

Diversas análises podem ser feitas a partir do grupo de incidentes selecionado nesta pesquisa. A seguir, serão apresentadas algumas relativas aos principais aspectos.

Quanto ao ramo do direito em discussão no tema delimitado para análise de admissibilidade pelos 51 acórdãos analisados, obtém-se o seguinte gráfico:

\section{Gráfico 2}

Ramo do direito da matéria delimitada para análise

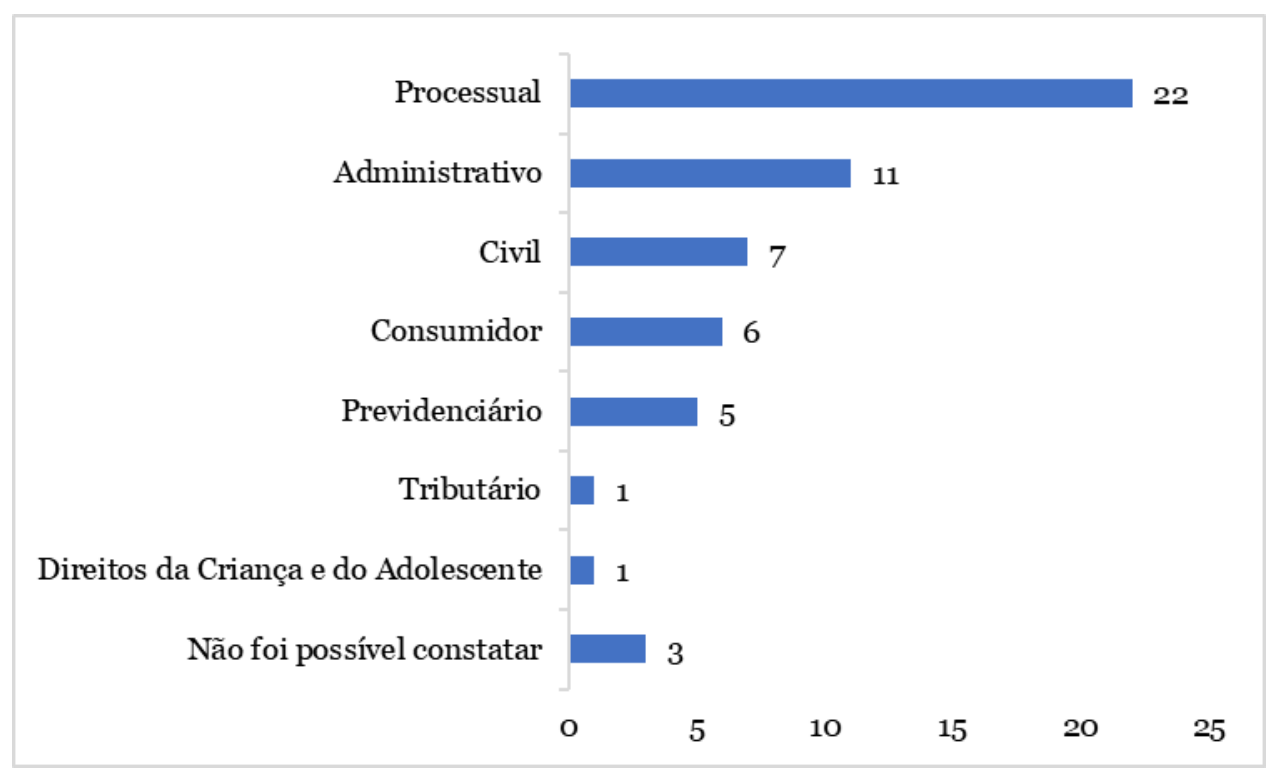

Fonte: Observatório Brasileiro de IRDRs. 
A contagem foi obtida isolando-se cada uma das ocorrências por ramo do direito. Por exemplo, um IRDR que trata de direito processual e direito do consumidor, concomitantemente, representa uma unidade na contagem de direito processual e uma unidade na contagem de direito do consumidor. Com isso, observa-se a predominância de Direito Processual, que está presente em $43,13 \%$ dos casos analisados.

Tendo em conta que existem 13 IRDRs suscitados em conflito de competência e que assumem matéria de Direito Processual, portanto, a classificação pode sofrer distorções. Em análise retirando esses casos, Direito Processual assume a quantia de nove IRDRs suscitados exclusivamente em processos que tramitam nos Juizados Especiais, colocando-o em segunda posição, à semelhança do que ocorre com os dados gerais obtidos no Relatório de Pesquisa (Zufelato et al., 2019, p. 66).

Entretanto, a existência de discussões processuais como essa, ainda que ocupe a segunda posição, indica uma deficiência do Sistema. Quando a investigação se atenta à filosofia-base de instituição dos Juizados Especiais, consubstanciada na facilidade de acesso e a aproximação do sistema de justiça para resolver o conflito do jurisdicionado de forma rápida e sem complicações, os dados demonstram a desvirtuação dessas intenções. Para a parte que se socorre ao processo diferenciado dos Juizados Especiais, o prolongamento de discussões processuais é de pouca relevância para o seu interesse na rápida resolução do conflito. Além, essas controvérsias distanciam a parte da discussão central do litígio, inundando-a em fases do processo pouco práticas.

Isso pode ser, inclusive, consequência da reprodução do procedimento comum nos Juizados Especiais, o que é capaz de ser explicado pela atuação simultânea de juízes nas varas dos Tribunais e nos Juizados Especiais, bem como pela dificuldade de penetração de novas regras, como apontado por Galanter (2018, pp. 110-111). Especialmente, há dificuldade de implementação de mudanças quando se atinge o núcleo do raciocínio empregado, promovendo verdadeira alteração de cultura, como bem evidenciada a qualificação dos Juizados Especiais como processo diferenciado. Cappelletti e Garth (1988, pp. 105-106) também se 
atentam à barreira que os juízes têm de abandonar o modelo de processo tradicional.

A dificuldade de implementação da racionalidade dos Juizados Especiais, orientada pelos princípios inscritos no art. $2^{\circ}$ a Lei $n^{\circ} 9.099 / 95$, conforme Carreira Alvim (2011, pp. 17-18), pode ser explicada pela estrutura deficitária que acarreta na atuação simultânea de juízes das varas comuns nos Juizados. Dado também revelado pelo relatório de pesquisa Diagnóstico sobre os Juizados Especiais Cíveis (2013, p. 17), o qual aponta que no Ceará e no Rio de Janeiro, respectivamente, $62,63 \%$ e 63,33\% dos juízes não são exclusivos do Juizado Especial, com a exceção de Amapá, em que $89,47 \%$ dos juízes são exclusivos.

Outro ponto que chama atenção é que, conforme identificado no Diagnóstico sobre os Juizados Especiais Cíveis (IPEA, 2013, pp. 19-20), a maior parte das demandas dos Juizados Especiais é de natureza consumerista. Já os dados sobre IRDR colhidos no Observatório Brasileiro de IRDRs, como visto, não colocam as demandas consumeristas em posição de destaque entre as matérias mais suscitadas, mas sim questões processuais e contra o Estado (Direito Administrativo) como principal objetivo de uniformização jurisprudencial.

Por sua vez, aspecto importante em decorrência dos temas delimitados nos incidentes suscitados é a origem legislativa do direito em discussão. Isso porque, diferentemente das outras técnicas de tratamento das demandas repetitivas, o IRDR aceita questões de direito estadual, distrital e/ou municipal.

Para a coleta deste dado, buscou-se a menção expressa a dispositivos de diplomas legais. Não foi considerada a atribuição de competência em abstrato para legislar sobre determinada questão, mas sim quem efetivamente legislou sobre o tema em análise. Para tanto, foram consideradas as menções expressas a dispositivos ou diplomas legais, isolando-se as ocorrências, considerando que um mesmo tema pode envolver mais de um ato normativo emanado por diferentes entes federados, obtendo-se o seguinte gráfico: 


\section{Gráfico 3}

Origem legislativa da questão de direito

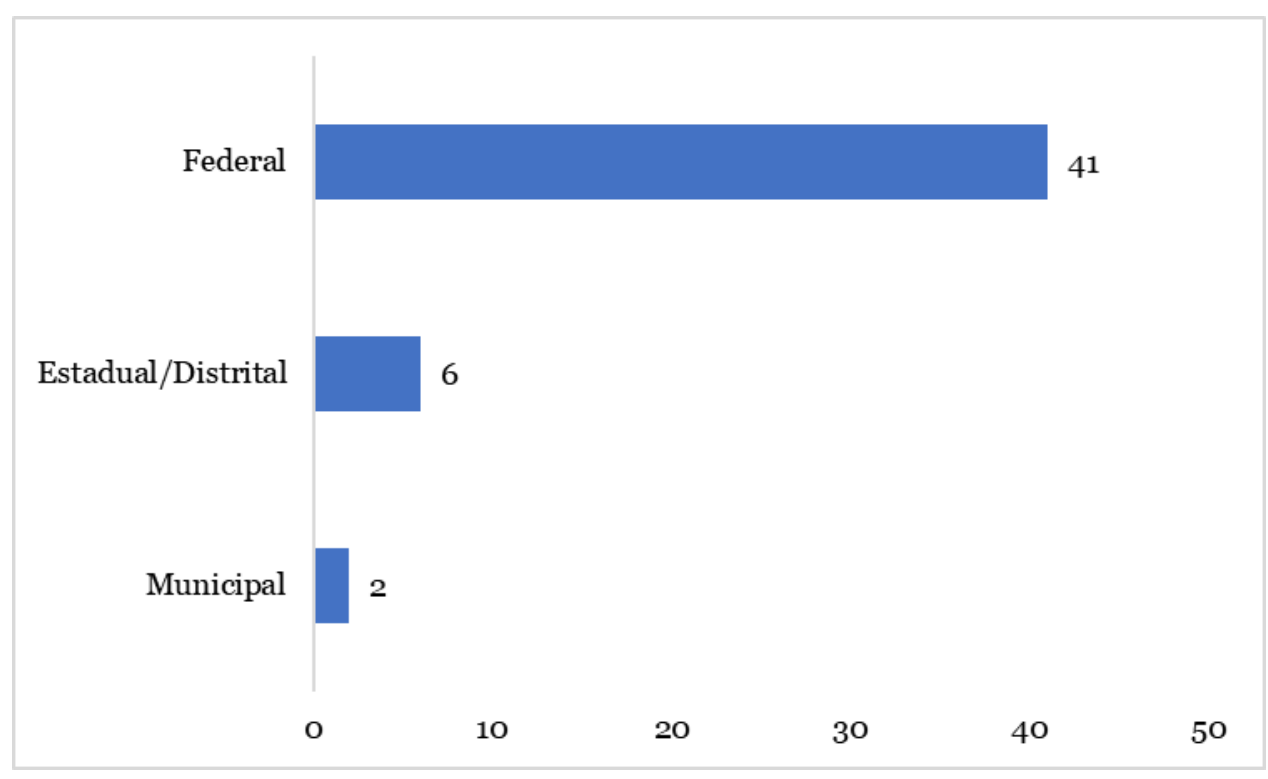

Fonte: Observatório Brasileiro de IRDRs.

A prevalência de questões federais é marcante, representando cerca de 80\% dos IRDRs que se relacionam aos Juizados Especiais. A mesma preponderância é observada nos dados referentes aos 677 incidentes da base completa do Observatório, em que caracteriza 71,78\% (Zufelato et al., 2019, p. 75).

Apesar do IRDR comportar questões de direito local, ele não é predominantemente utilizado para questões de direito nesse nível. Assim, o IRDR trata de questões federais que poderiam também ser objeto de outros instrumentos processuais, como a técnica de recursos repetitivos ou os próprios mecanismos (incidentes) de uniformização dos Juizados. Com isso, é possível que haja tratamento diverso nos Tribunais brasileiros, com teses vinculantes, sobre um mesmo tema - o que, a princípio, vai de encontro à própria razão de ser do IRDR na tentativa de promover isonomia e segurança jurídica. A uniformidade nacional da tese julgada, entretanto, é condicionada ao julgamento do mérito do recurso especial ou recurso extraordinário interposto contra o acórdão de mérito do IRDR, os quais terão a tese jurídica adotada pelo STJ ou STF aplicada, vinculativamente, em todo o território nacional - conforme dispõe o $\S 2^{\circ}$ do art. 987 do CPC. 
Também foi considerado o resultado do exame de admissibilidade dos IRDRs em estudo, se admitido ou não admitido. Não houve nenhum resultado diverso, como convertido em diligência ou extinto, como se vê:

\section{Gráfico 4}

Resultado do exame de admissibilidade

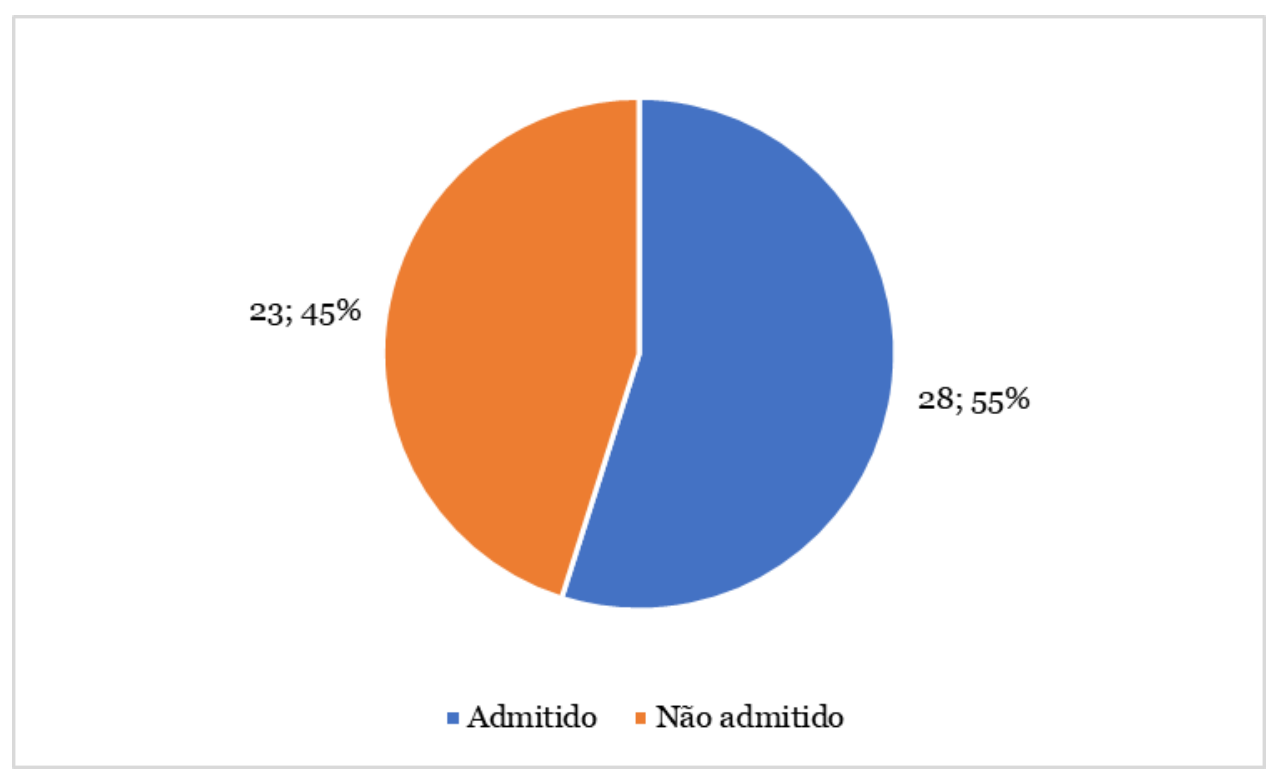

Fonte: Observatório Brasileiro de IRDRs.

É equilibrada a proporção entre admitido e não admitido. Contudo, ao analisar quem suscitou o incidente é possível perceber diferenças no índice de sucesso referente ao resultado do exame de admissibilidade, conforme se verá mais adiante.

Quanto à natureza do suscitante, é possível constatar em quantos incidentes houve iniciativa da parte do processo originário, do membro do Poder Judiciário (como juízes e desembargadores), e outros legitimados. Os resultados são os seguintes:

\section{Gráfico 5}

Natureza do suscitante 


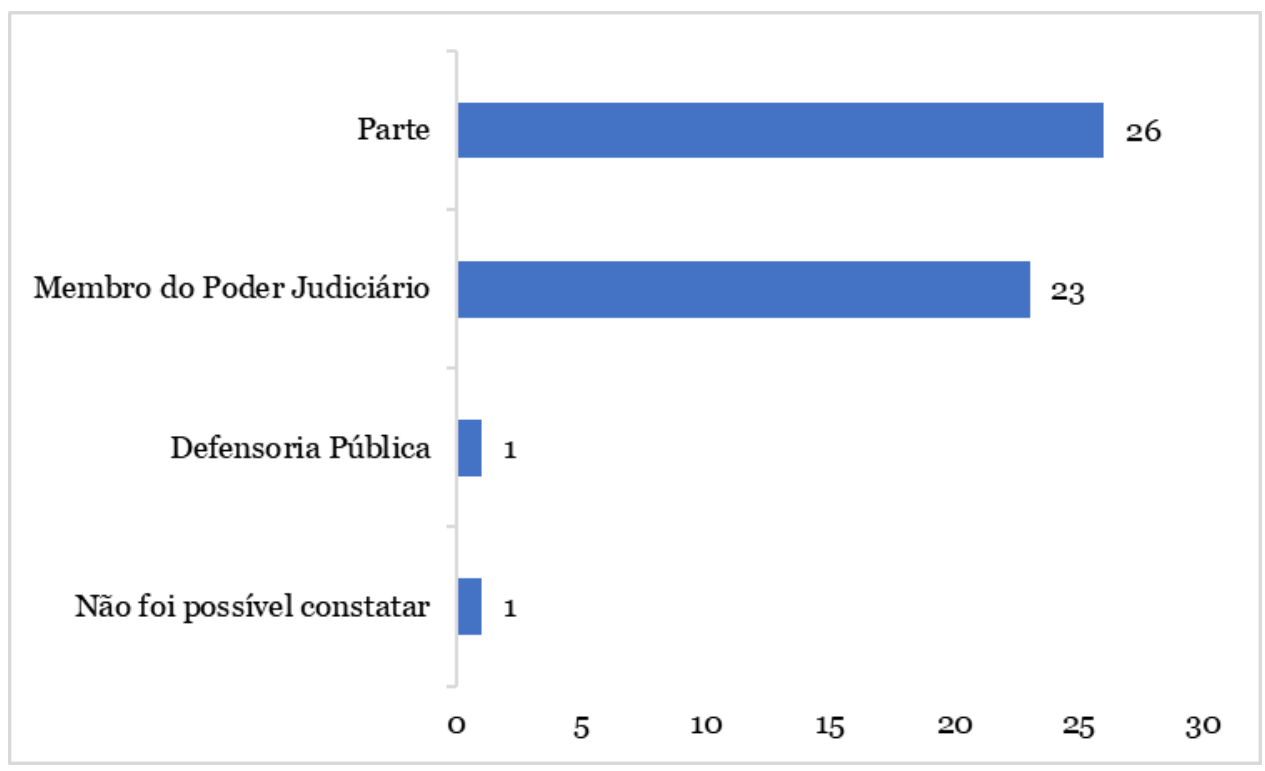

Fonte: Observatório Brasileiro de IRDRs.

Como se nota, há grande prevalência de atuação das partes do processo originário e dos membros do Poder Judiciário, havendo apenas uma ocorrência quanto aos demais legitimados, representada pela Defensoria Pública. Apesar de ambos serem expressivos na suscitação do IRDR, o resultado do exame revela diferenças significativas em relação à quantidade de IRDRs admitidos pelas partes e por membros do Poder Judiciário, conforme consta no gráfico:

\section{Gráfico 6}

Resultado do exame por natureza do suscitante

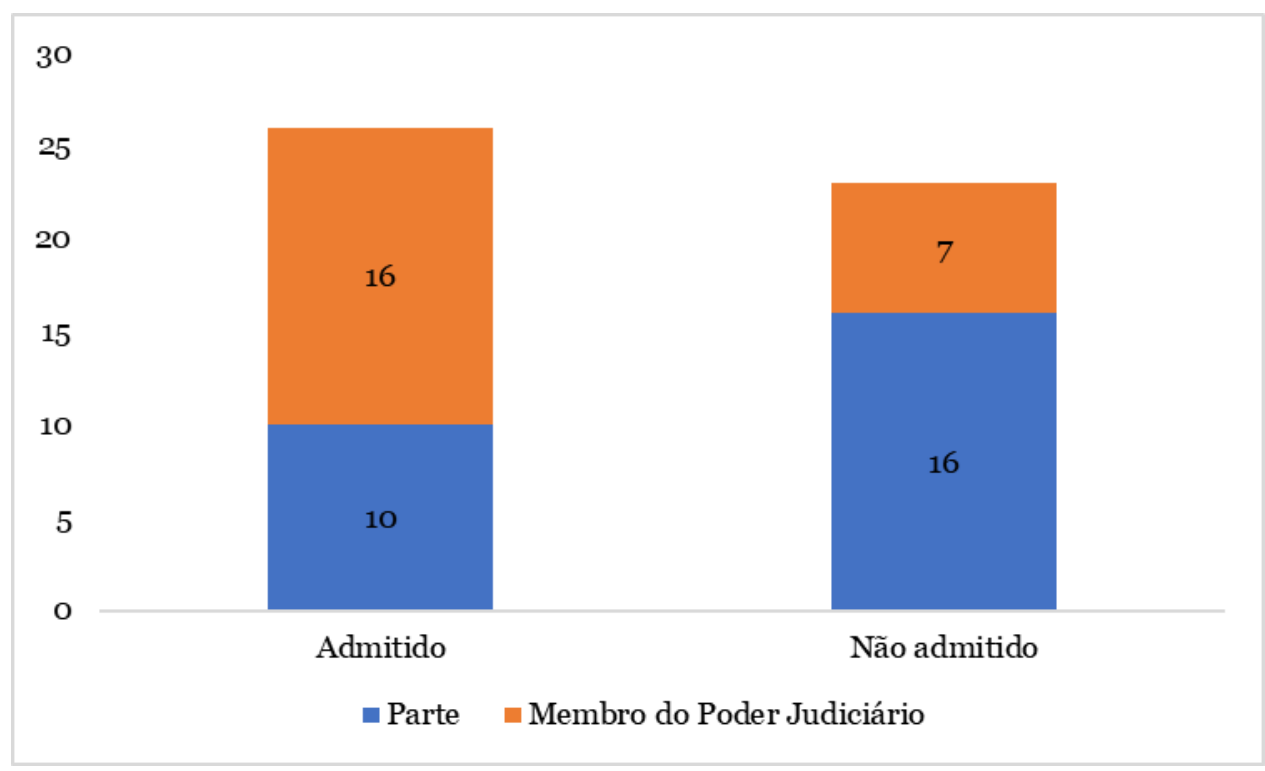


Fonte: Observatório Brasileiro de IRDRs.

O "índice de sucesso", considerando sucesso na suscitação do incidente quando ocorre a sua admissão, é maior para aqueles que foram de iniciativa de membros do Poder Judiciário, como juízes, tanto dos Juizados Especiais que exercem primeiro ou segundo grau de jurisdição ou ocupam posição de órgãos de uniformização, tanto dos Tribunais, e desembargadores. Nesses casos, 69,50\% das suscitações foram admitidas, contra 38,40\% de admissão dos incidentes suscitados pelas partes.

A mesma tendência também se encontra em relação à totalidade da base de dados do Observatório quanto aos incidentes suscitados e com exame de admissibilidade realizado até 15 de junho de 2018. De fato, o I Relatório do Observatório Brasileiro de IRDRs identifica que os membros do Poder Judiciário têm mais sucesso na admissão, representando $61 \%$ de todos os incidentes admitidos, mesmo sendo as partes os maiores suscitantes. 6

Em relação aos suscitantes-partes, é possível pormenorizar a análise para verificar se a parte suscitante do processo originário compõe o polo ativo ou o polo passivo da demanda, bem como sua natureza: se pessoa física, pessoa jurídica de direito privado ou pessoa jurídica de direito público. Constata-se, então, de acordo com as cinco matérias mais suscitadas:

\section{Gráfico 7}

Suscitante (parte) em matéria processual

\footnotetext{
${ }^{6}$ Quanto à análise dos suscitantes, o I Relatório de Pesquisa do Observatório Brasileiro de IRDRs (Zufelato, 2019, pp. 60-61) e o artigo de Camilo Zufelato e Fernando A. Oliveira (2019, pp. 1-30).
} 


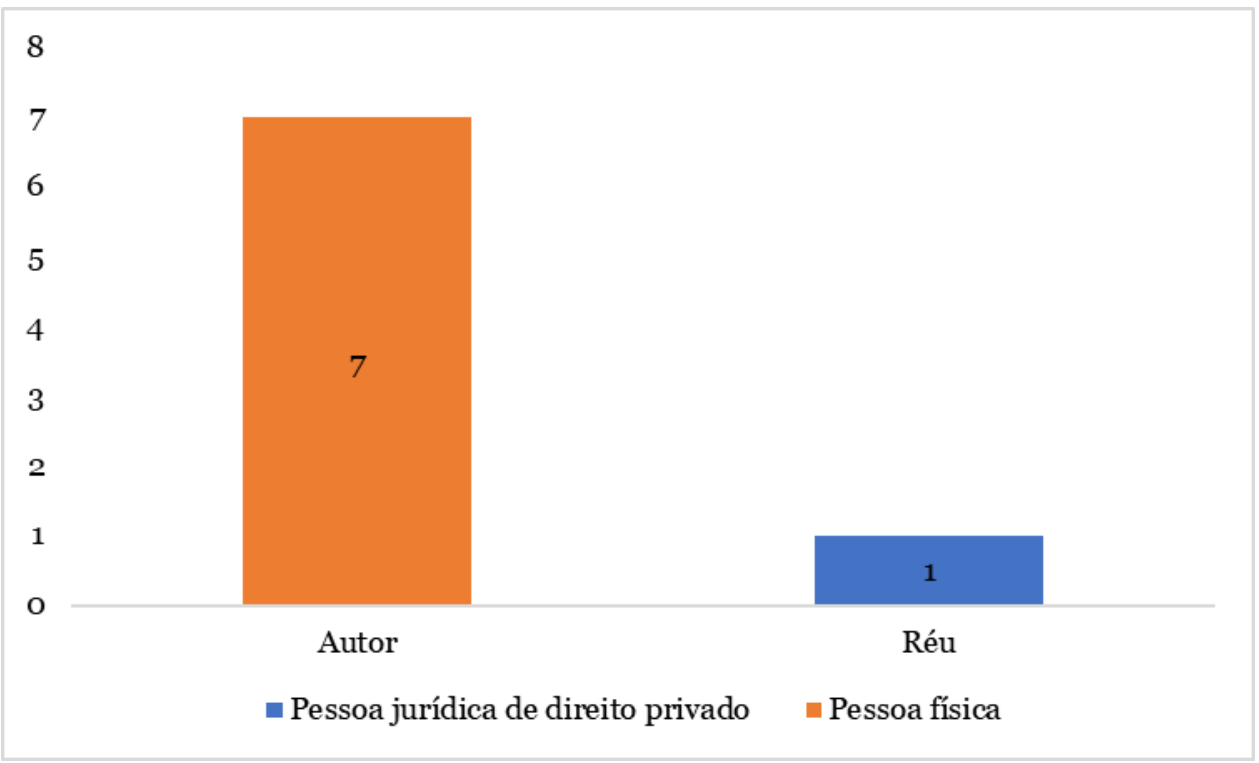

Fonte: Observatório Brasileiro de IRDRs.

\section{Gráfico 8}

Suscitante (parte) em matéria administrativa

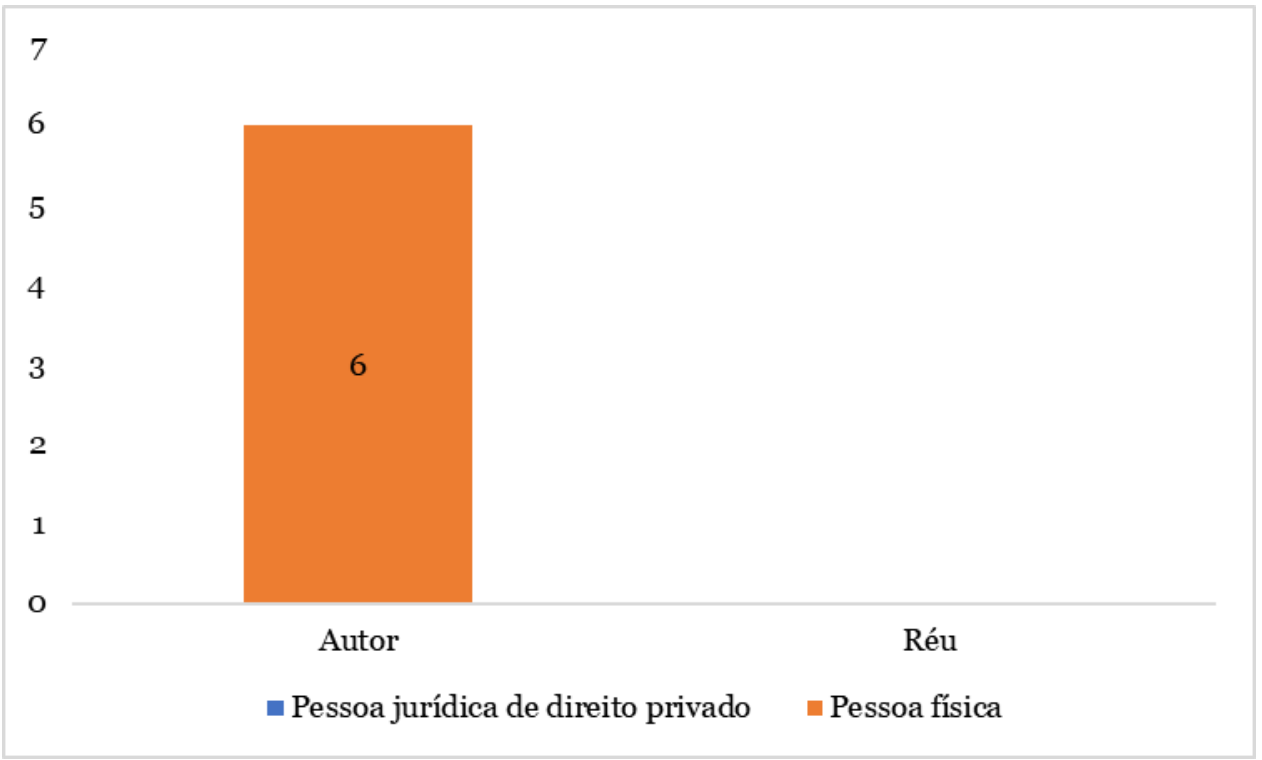

Fonte: Observatório Brasileiro de IRDRs.

\section{Gráfico 9}

Suscitante (parte) em matéria cível 


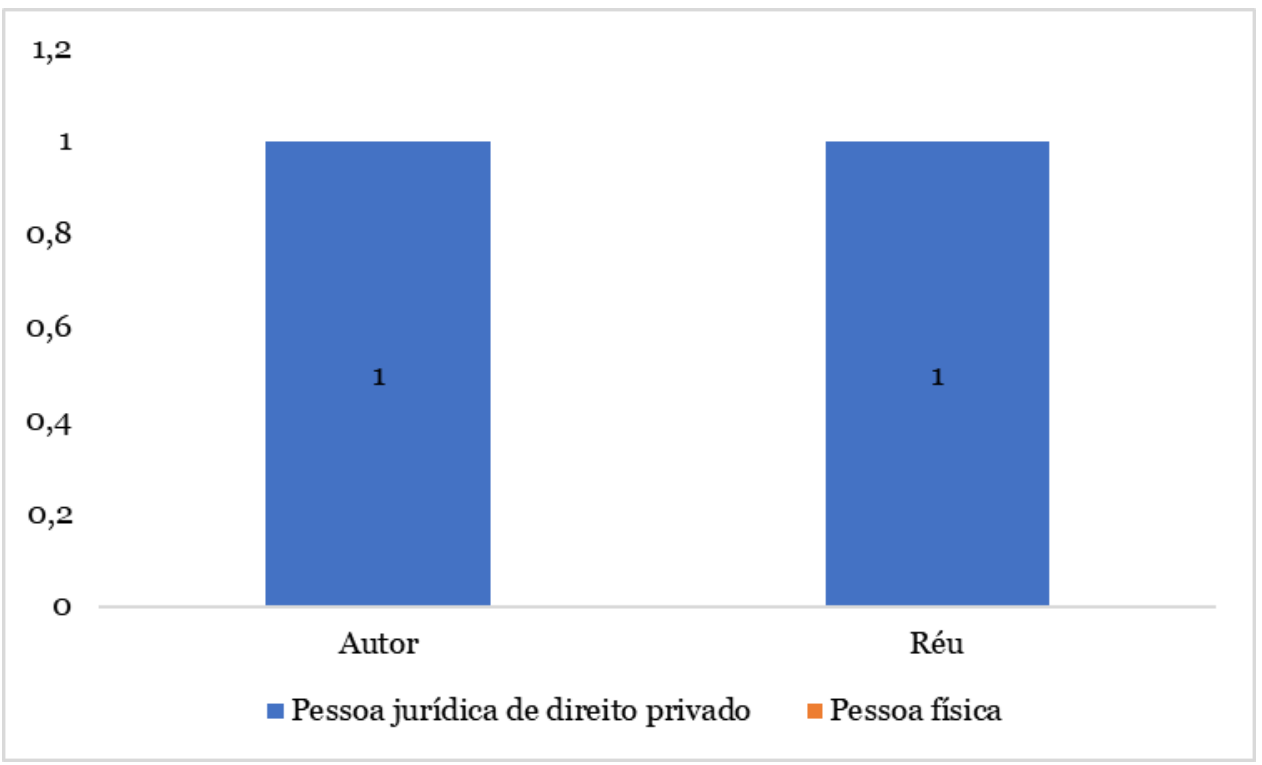

Fonte: Observatório Brasileiro de IRDRs.

\section{Gráfico 10}

Suscitante (parte) em matéria consumerista

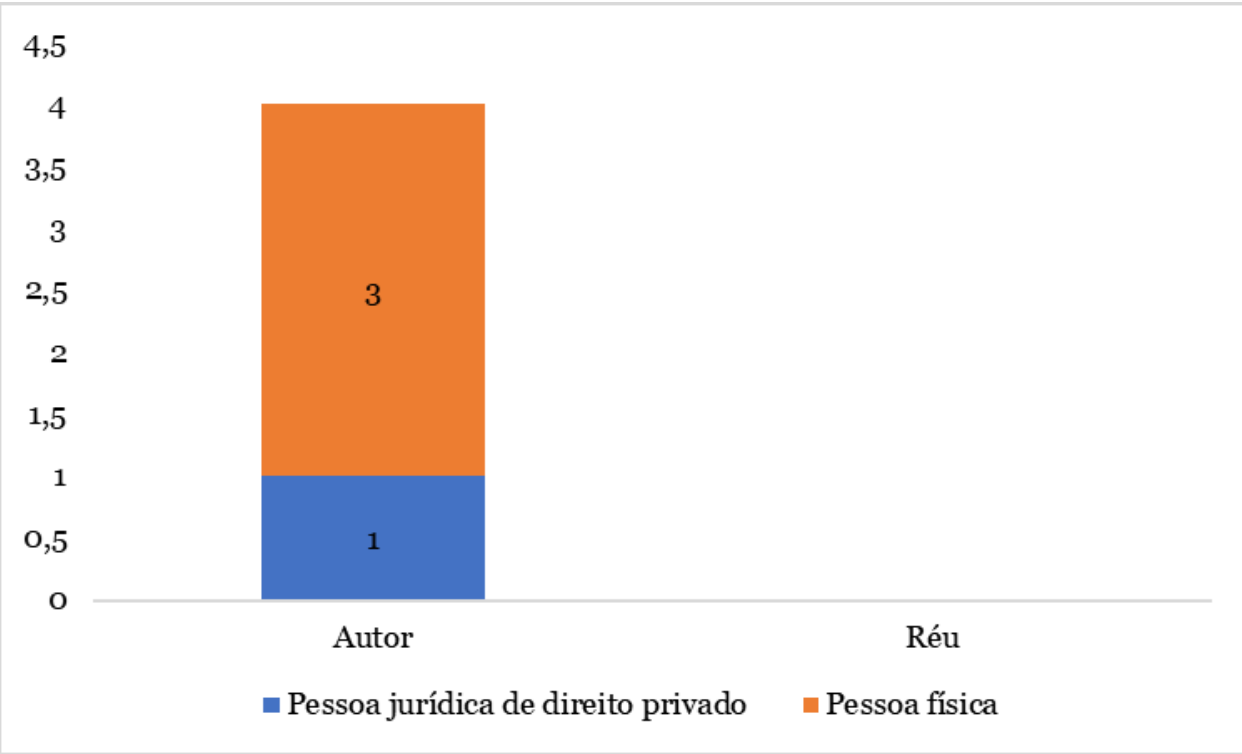

Fonte: Observatório Brasileiro de IRDRs.

\section{Gráfico 11}

Suscitante (parte) em matéria previdenciária 


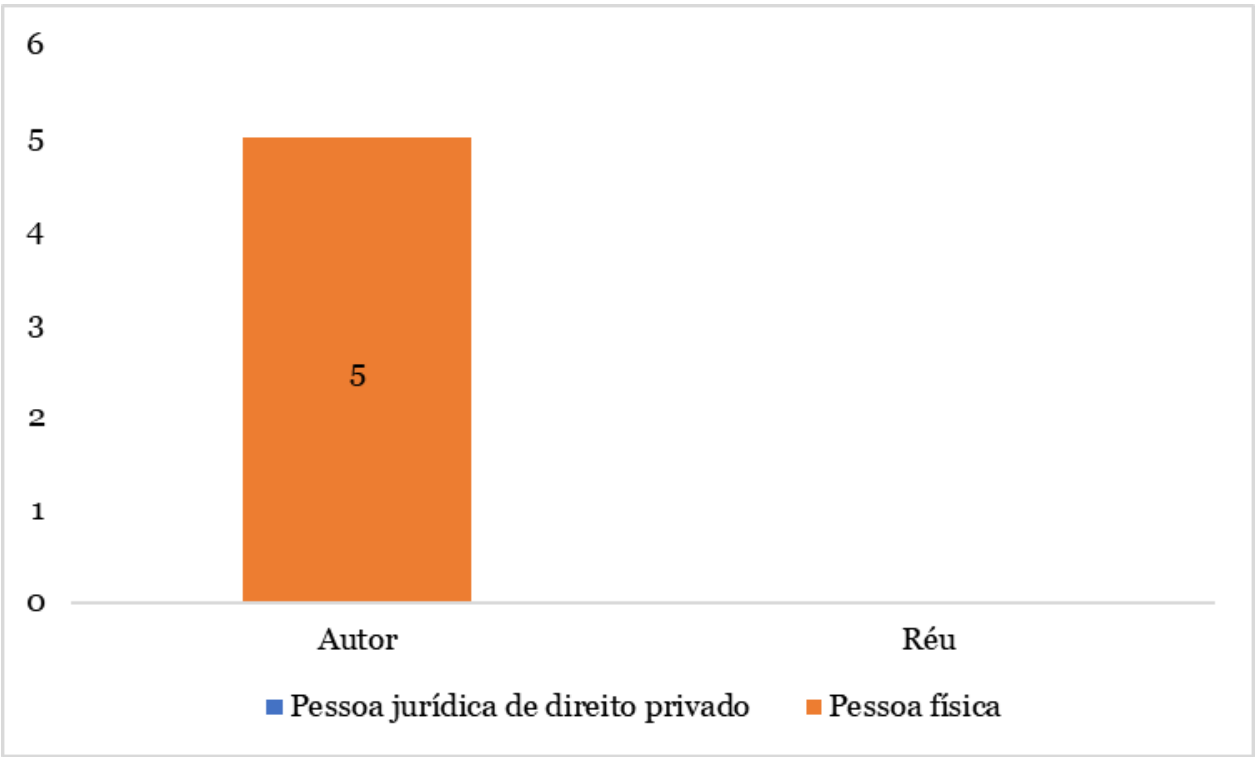

Fonte: Observatório Brasileiro de IRDRs.

Com isso, percebe-se que, nas matérias selecionadas, em apenas dois casos o IRDR foi suscitado pelo réu, em ambas as situações sendo pessoa jurídica de direito privado. Considerável parte das suscitações, então, foram feitas pelo autor, que corresponde ao total de 23 casos, no qual são 21 de pessoas físicas e 2 de pessoas jurídicas de direito privado. Sobrepuja a atuação de autores pessoas físicas na suscitação de IRDR, justamente aqueles que se socorrem ao Poder Judiciário para a solução de algum conflito.

Ainda é importante destacar os casos em que o IRDR foi utilizado como sucedâneo recursal, prática recorrente constatada pelo Observatório (Zufelato et al. 2019, p. 78). Para isso, considerando apenas os IRDRs suscitados pela parte autora e inadmitidos, que correspondem a 16 casos, em 9 deles (56,25\%) o IRDR foi manejado como sucedâneo recursal. São processos que não possuem mais pendência de julgamento, estando o caso julgado, portanto, e tentou-se reverter a decisão judicial por meio do IRDR, o qual não é o instrumento adequado para essa finalidade, sendo por óbvio a sua inadmissão.

\section{INADMISSIBILIDADE NO TRIBUNAL DE IRDRS SUSCITADOS EM PROCESSOS DOS JUIZADOS ESPECIAIS}


Nesse tópico, serão analisados os incidentes que foram inadmitidos por terem sido suscitados a partir de processos em trâmite perante os Juizados. No tópico seguinte, o exame será dos incidentes admitidos, embora suscitados a partir de processos oriundos dos Juizados.

Para fins de análise quanto à relação da inadmissão com os Juizados Especiais, foram cruzados os dados dos IRDRs não admitidos suscitados a partir de processos dos Juizados Especiais com a fundamentação dispendida no acórdão do exame de admissibilidade. O formulário de coleta de informações utilizado pelo Observatório contava com a verificação do enfrentamento pelo acórdão do julgamento do exame de admissibilidade de três requisitos: i. risco de ofensa à isonomia e à segurança jurídica; ii. efetiva repetição de matéria exclusivamente de direito; e iii. o art. 976, $\S 4^{\circ}, \mathrm{CPC}$ (requisito negativo referente à ausência de recurso repetitivo afetado sobre o mesmo tema).

Com isso, apenas aqueles IRDRs cuja fundamentação de requisito não cumprido estava vazia é que foram analisados aqui para investigar a razão da inadmissão, e se ela está relacionada com a causa pendente de julgamento no Tribunal. Desconsiderou-se os IRDRs que tiveram algum requisito do artigo 976 do CPC não cumprido porque, de qualquer forma, a ausência de qualquer deles já implicaria em inadmissão. Nesses casos, não é possível concluir que a inadmissibilidade é em razão do processo de origem ser dos Juizados Especiais, porque, em muitas vezes, os órgãos julgadores não analisam a presença de todos os requisitos quando verificam a ausência de um deles de plano.

São 12 IRDRs que se encontram nesses parâmetros, enquanto os demais 6 incidentes foram inadmitidos pelos requisitos "usuais" expressos no formulário de coleta de dados - os requisitos do artigo 976 do CPC. Naqueles parâmetros, verificando as motivações que levaram à não admissão, tem-se:

\section{Gráfico 12}

Fundamentação pela inadmissibilidade dos IRDRs nos casos em que não houve marcação de requisito não cumprido 


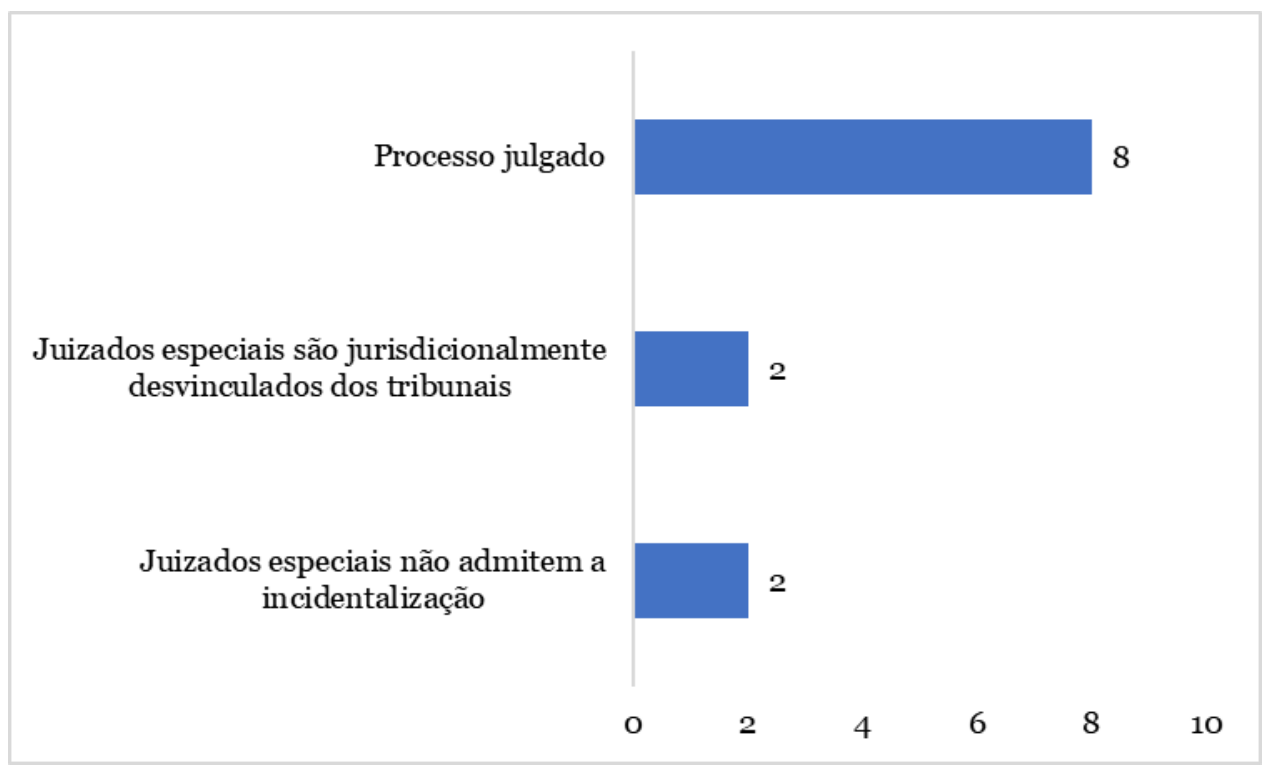

Fonte: Observatório Brasileiro de IRDRs.

O motivo mais recorrente para inadmissão foi a utilização do IRDR como um sucedâneo recursal. Como já exposto acima, para ser suscitado, o IRDR depende da possibilidade de reforma da decisão de mérito do processo originário, seja sentença ou acórdão, diante da cisão de cognição que se opera pelo julgamento do IRDR. Isso porque ele não é sucedâneo recursal ou meio de impugnação, mas se destina à uniformização de questão de direito repetitiva, exigindo a necessidade de interesse e, portanto, a possibilidade de aplicação da tese fixada no processo em que foi suscitado.

A outra parte dos dados separados, que se relaciona diretamente com os Juizados Especiais, tem 2 incidentes para cada hipótese, o que demonstra que ainda são poucos os acórdãos que se debruçaram sob o aspecto da inadmissão em razão dos Juizados Especiais.

Dois acórdãos7 fundamentam que os Juizados Especiais não admitem a incidentalização processual, por ser um processo pautado na simplicidade, informalidade e celeridade. O objetivo de quem ingressa com uma ação perante os Juizados Especiais seria a de ter provimento jurisdicional rápido e simples, o

\footnotetext{
${ }^{7}$ São os IRDRs de n 0033332-60.2017.8.19.0000 e n 0056634-21.2017.8.19.0000, ambos do Tribunal de Justiça do Estado do Rio de Janeiro.
} 
que não comportaria incidentalização procedimental tal qual é o IRDR. Os dois acórdãos são exatamente iguais na fundamentação com o seguinte excerto:

Assim, não há como se admitir a arguição do IRDR na presente hipótese, perante as Seções Cíveis, ressaltando-se que o sistema dos Juizados Especiais é mais célere, mas não admite incidentes, além de ter um sistema de processamento e recursal diverso.

Ao não admitir a incidentalização, o julgador aplicou o raciocínio de que o processo dos Juizados Especiais é voltado, primordialmente, à célere resolução do conflito de forma simples e informal - como demanda as características da litigiosidade contida. Assim, apesar de ir de encontro à prática forense de reprodução do procedimento comum nesse ambiente, o julgado é congruente com a sistematicidade e principiologia das leis dos Juizados Especiais. Contudo, tal elemento não é o único capaz de afastar por si só a possibilidade de suscitação de IRDR a partir desses processos, sendo a questão mais densa que o julgador findou com tal argumento.

Há também dois acórdãos8 com fundamentos no sentido de que os Juizados Especiais não estão jurisdicionalmente vinculados ao Tribunal; e que não se admite o prosseguimento do IRDR porquanto apenas as turmas recursais são as competentes para revisar as decisões de primeiro grau dos Juizados, ao passo que um incidente julgado pelo Tribunal feriria tal competência.

Sobre esse fundamento, no âmbito do IRDR nº 0000586-86.2017.8.03.0000, do TJAP, justifica-se dessa forma:

A redação desse dispositivo revela peculiaridade do incidente relativamente ao Sistema dos Juizados Especiais. Explico: se por um lado os efeitos dos enunciados aprovados em sede de IRDR devem ser observados pelos Juizados Especiais, por força do art. 985, I, do CPC, por outro, por falta

\footnotetext{
${ }^{8}$ São os IRDRs de n 0000586-86.2017.8.03.0000, do Tribunal de Justiça do Estado do Amapá, e o de n²018727-80.2017.8.26.0000, do Tribunal de Justiça do Estado de São Paulo
} 
de previsão legal, é inviável a instauração do incidente a partir de processos que tenham curso nos Juizados, tendo em vista que deles não caberá recurso ao Tribunal de Justiça.

Não é demais salientar que no microssistema do Juizado Especial o julgamento de recursos se dá pela Turma Recursal, composta por juízes de Primeiro Grau, conforme preconiza o art. 41 da Lei Federal n9.099/95.

Contudo, cabe aqui a discussão sobre a ausência de natureza recursal do IRDR e a incidentalização objetivada do IRDR, que desloca apenas a questão de direito para apreciação, separadamente do processo originário, mas sem desconsiderar as questões de fato envolvidas no direito. Com isso, não estaria ferida a competência recursal própria dos Juizados Especiais.

Sobre o mesmo assunto, no IRDR n²018727-80.2017.8.26.0000, do TJSP, encontra-se a seguinte explicação:

Revela-se nesse ponto curiosa a relação entre o IRDR e os Juizados Especiais, pois, se por um lado estes últimos se submetem aos efeitos dos enunciados aprovados em sede de IRDR nos termos do artigo 985, inciso I do Código de Processo Civil, por outro os feitos em trâmite neles não podem ser originários do IRDR por não ser de competência do Tribunal o julgamento de seus recursos.

Assim, por vezes a natureza jurídica do IRDR pode causar confusão, especialmente no que se refere à causa pendente. Ser ela um requisito de admissibilidade ou não é objeto de mais denso estudo que demanda maior aprofundamento.9 Aqui, far-se-á análise das consequências dos dois cenários. Caso entendido que o IRDR necessite de causa pendente de julgamento em segunda instância, pois o Tribunal julgará ao mesmo tempo o IRDR e o recurso, remessa necessária ou ação originária, haveria real impossibilidade de julgamento

\footnotetext{
${ }^{9}$ Sobre o tema: Temer, 2017, p. 107; Cavalcanti, 2016, p. 225; Oliveira, 2019, p. 170.
} 
de IRDR proveniente dos Juizados Especiais, visto que eles possuem complexo recursal e órgãos próprios.

Entretanto, caso entendido que o IRDR se aproxima da técnica de procedimento modelo, e não de causa piloto como na hipótese anterior, poderia haver a cisão de julgamento do IRDR com o processo que deu origem a ele, sendo aí possível o julgamento de IRDR suscitado em processo que tramita nos Juizados Especiais pelo Tribunal, e com a aplicação da tese vinculante em toda a área de jurisdição deste. Esse assunto será enfrentado no próximo capítulo.

Para além desses argumentos dispendidos nos julgados ora analisados, Monnerat (2017, pp. 508-509), considerando o tipo de processo existente nos Juizados Especiais, voltados à resolução célere de conflitos de baixa complexidade e valor econômico, ainda destaca que a suscitação de IRDR a partir deles é incompatível, em razão da simplicidade.

\section{ADMISSIBILIDADE NO TRIBUNAL DE IRDRS SUSCITADOS EM PROCESSOS DOS JUIZADOS ESPECIAIS}

Em relação aos acórdãos da primeira fase do IRDR (exame de admissibilidade), relevantes questões são levantadas pelos Tribunais para processarem e julgarem os incidentes suscitados a partir de processos que tramitam nos Juizados Especiais.

O Tribunal de Justiça do Estado de Minas Gerais (TJMG), no IRDR n 0124879-52.2017.8.13.0000, apesar de ter explicitado que a causa pendente de julgamento no Tribunal é um requisito de admissibilidade do IRDR, afastou esse requisito para admitir o processamento daquele incidente. $O$ tema delimitado para exame foi a competência dos Juizados Especiais Cíveis para dirimir conflitos sobre o fornecimento de água e danos decorrentes do rompimento da barragem de Fundão em Mariana/MG. Assim, explica o relator que a discussão nunca poderia chegar aos Tribunais, já que os órgãos competentes para a reforma das decisões dos juízes dos Juizados Especiais são as turmas recursais, e a divergência jurisprudencial acontece apenas no âmbito dos Juizados Especiais. 
Essa é uma das deficiências dos Juizados apontadas por Mendes (2017, p. 153), quanto à inexistência de mecanismos capazes de realizar a uniformização no âmbito dos Juizados Especiais não regidos pelas Leis $n^{\circ}$ 10.259/2002 e 12.153/2009 ou referente a assuntos tratados ao mesmo tempo tanto nos Juizados quanto na Justiça Comum, destacando o importante papel do IRDR em suprir essa lacuna para manter a uniformidade jurisprudencial nesses dois níveis. Por isso mesmo, o TJMG admitiu o IRDR, afastando o requisito da causa pendente diante da peculiaridade do caso, vez que

[...] O IRDR tem por escopo alcançar à segurança jurídica e à isonomia de modo abrangente e irrestrito, pelo que não se pode limitar sua aplicação em razão de requisito que fora estabelecido, claramente, tendo em vista a tramitação dos processos na Justiça Comum.

O julgamento não foi unânime, havendo vozes contrárias à admissão do IRDR por não ter sido suscitado em processo pendente de julgamento no tribunal.

Outra peculiaridade do caso foi a suspensão apenas dos IRDRs que tramitam nos Juizados Especiais, deixando os processos que tramitam perante as Varas Cíveis e no Tribunal terem andamento habitual. Isso em razão da própria controvérsia, porque ela surge apenas nos processos dos Juizados. Segundo a decisão, não haveria sentido e justificativa o sobrestamento de processos que não seriam afetados pela tese fixada ao final do julgamento.

Entretanto, se a fixação da tese vinculante ao final será aplicada tanto nos processos dos Juizados Especiais quanto no dos Tribunais, para assegurar a finalidade do sobrestamento, que é evitar a proliferação de decisões divergentes, seria necessário suspender todos os processos sob a área de jurisdição do Tribunal em questão.

O Tribunal Regional Federal da $4^{\circ}$ Região (TRF4) tem jurisprudência consolidada e seguida em todos os demais casos semelhantes, no sentido de ser admissível IRDR suscitado a partir de processos dos Juizados Especiais. A dicção 
do acórdão de admissibilidade no IRDR n 5033207-91.2016.4.04.0000 é a base para a formação do entendimento do Tribunal, o qual considerou que:

[...] a Constituição, ao determinar que o legislador estabeleça o julgamento de recursos nos Juizados Especiais obrigatoriamente por turmas de juízes de primeiro grau - imposição relativa à composição da Turma Recursal -, não proíbe que o legislador vincule essa mesma Turma Recursal a precedente obrigatório do Tribunal da respectiva região. A vinculação da Turma Recursal a precedente obrigatório do Tribunal Regional não implica, portanto, previsão de julgamento de recursos dos Juizados Especiais pelo TRF, razão pela qual não há falar em inconstitucionalidade.

Ocorre a devida separação entre a atividade própria do complexo recursal dos Juizados Especiais, no sentido de serem os competentes para a reanálise de julgados de primeiro grau, e a vinculação dos juízes dos Juizados Especiais quanto a precedentes vinculantes hierárquicos. Os Juizados, na esteira do que é defendido neste trabalho, estão inseridos dentro do mesmo sistema de justiça, devendo observar os precedentes obrigatórios emanados pelos órgãos jurisdicionais superiores.

No IRDR n5016985-48.2016.4.04.0000, do TRF4, inicialmente há o voto do relator contrário à admissão do incidente. Isso porque o processo em que foi suscitado é dos Juizados Especiais, os quais estão desvinculados dos Tribunais, e porque estes nunca poderiam apreciar questão de processos dos Juizados Especiais, vez que nesse Sistema existe complexo recursal próprio. Contudo, seguindo a orientação anteriormente firmada no TRF4, o relator proferiu voto complementar mudando seu posicionamento e admitindo o incidente, seguido por unanimidade, nos termos:

A compreensão majoritária é no sentido de que o novo CPC, ao dar ao Tribunal de apelação a competência para decidir o IRDR, com aplicação explícita do resultado do julgamento a todos os processos que tramitem na 
sua área de jurisdição, inclusive àqueles que tramitem nos Juizados Especiais do respectivo Estado ou Região, no mínimo implicitamente admitiu que os incidentes sejam instaurados a partir de processos que tramitam nos juizados especiais. A submissão dos Juizados ao que decidido no IRDR, segundo entendeu a Corte, veio justamente para evitar tratamentos diversos para temas de direito por parte dos juizados especiais e da justiça ordinária, o que já ocorreu em diversas ocasiões, gerando perplexidade entre os jurisdicionados. Como por opção do legislador a orientação do Tribunal sempre deverá preponderar, não há razão para que se exclua a possibilidade de instauração de IRDR a partir de processos que tramitam nos Juizados Especiais.

Já o IRDR nº 042228-49.2016.8.16.0182, do Tribunal de Justiça do Estado do Paraná (TJPR), teve solução curiosa. Foi suscitado pela juíza do $4^{\circ}$ Juizado Especial da Fazenda Pública do Foro Central da Região Metropolitana da Comarca de Curitiba e apreciado pela Seção Cível Ordinária do TJPR. O Tribunal considerou necessária a presença do requisito da causa pendente de julgamento, o que é impossível em suscitações a partir de processos dos Juizados Especiais. Porém, tendo em vista a importância de se resolverem as demandas repetitivas isonomicamente, o IRDR foi desassociado do processo dos Juizados Especiais e vinculado na apelação cível $n^{\circ} 1.675 .534-5$, que está pendente de julgamento no Tribunal. Essa resposta do Tribunal é semelhante com a proposta de Cavalcanti (2016, p. 229), em que é possível a suscitação de IRDR desde que exista pendência da causa repetitiva no Tribunal em pelo menos um processo ainda em trâmite. Entretanto, foi o próprio Tribunal que alterou o processo em que o IRDR foi suscitado, a fim de retirá-lo do âmbito dos Juizados Especiais e admiti-lo. Vale destacar que essa não é uma posição unânime na doutrina, nem na jurisprudência, como visto.

Observa-se que o TRF4 também tem admitido os incidentes provenientes dos Juizados Especiais, conforme se observa na fundamentação dos IRDRs mencionados. Nesse Tribunal, os casos de inadmissão observados e que 
envolveram algo dos Juizados são por descumprimento de algum dos outros requisitos, que é o que aconteceu no IRDR n5012947-56.2017.4.04.0000, pelo

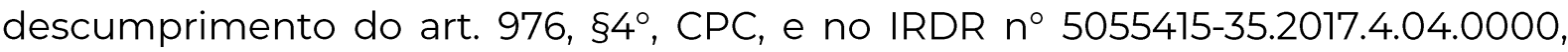
pela ausência de risco de ofensa à isonomia e à segurança jurídica. Contudo, ao contrário da prática do Espírito Santo (que julga incidentes a partir de processos dos Juizados em órgão próprio), o TRF4 julga os IRDRs oriundos de processos do Juizado em órgãos do próprio Tribunal, a exemplo do IRDR n $5049073-$ 08.2017.4.04.0000 suscitado pela Turma Regional de Uniformização dos Juizados Especiais Federais e admitido para processamento pela $2^{a}$ Seção. Nos fundamentos, o TRF4 destaca que privilegia a uniformização do direito nas duas esferas de jurisdição, em contraponto à existência de duas bolhas incomunicáveis que podem gerar entendimentos conflitantes.

Por fim, anota-se que dentre os IRDRs objeto de análise neste artigo que foram admitidos, oito tiveram o mérito julgado no recorte temporal adotado.10

\section{JULGAMENTO DO IRDR PELOS ÓRGÃOS DOS JUIZADOS ESPECIAIS}

Uma das possibilidades apontada pela doutrina de Mendes e Romano Neto (2015, p. 167) quando a suscitação de IRDR se der em processo que tramita perante os Juizados Especiais é o julgamento de admissibilidade e mérito realizado pelos seus próprios órgãos. Alguns Tribunais de Justiça, ao regulamentar os seus respectivos Juizados Especiais Cíveis, criaram órgãos e mecanismos de uniformização de jurisprudência no âmbito dos Juizados Especiais Cíveis, a espelho dos já existentes nos Juizados Especiais da Fazenda Pública e Federais.

Assim fez, por exemplo, o Tribunal de Justiça do Estado de São Paulo, com a edição da Resolução 589/2012, o Tribunal de Justiça do Estado de Minas Gerais, com a Instrução $n^{\circ} 1$ de 11 de outubro de 2011, e o Tribunal de Justiça do Estado do

\footnotetext{
10 São os IRDRs $n^{\circ}$ 5033207-91.2016.4.04.0000 do TRF4, $n^{\circ}$ 0124879-52.2017.8.13.0000 do TJMG, $n^{\circ}$ 0007164-87.2016.8.25.0000 do TJSE, $n^{\circ}$ 039/2016 da TUILF/ES, $n^{\circ}$ 040/2016 da TUILF/ES, $n^{\circ}$ 001961181.2016.8.08.0000 do TJES, $n^{\circ}$ 0026387-27.2016.8.07.0000 do TJDFT e $n^{\circ} 0012825-14.2017 .8 .07 .0000$ do TJDFT.
} 
Espírito Santo, com a Resolução n²3/2016. Este último caso, em específico, previu a competência do órgão criado na normativa para o julgamento de IRDR suscitado em processo de que tramita perante os Juizados Especiais, conforme a redação:

Art. 41. Compete à Turma de Uniformização de Interpretação de Lei:

$[\ldots]$

II - processar e julgar incidentes de resolução de demandas repetitivas e assunção de competência afetas ao sistema dos Juizados Especiais;

A Resolução ainda aduz, no art. 58, que é incabível a admissão de IRDR pelos Juizados Especiais quando no Tribunal já houver sido admitido algum com identidade de matéria. Mendes (2017, p. 166) destaca que esse é um requisito negativo de admissibilidade comparável ao sugestionado pelo art. $976, \S 4^{\circ}, \mathrm{CPC}$, que trata da impossibilidade de admissão do incidente quando houver recurso repetitivo afetado pelo STJ ou STF. Portanto, haveria inadmissibilidade quando um órgão de hierarquia superior estiver criando precedente obrigatório.

Quanto à tramitação do incidente nesse âmbito, o TJES determinou que o julgamento de admissibilidade do IRDR, quando suscitado perante a Turma de Uniformização de Interpretação de Lei, será proferido pelo relator designado em decisão monocrática. Tal disposição, de julgamento monocrático, vai na contramão do que se observa no artigo 978, parágrafo único, do CPC, e no caráter plural dos Tribunais.

No âmbito da Turma de Uniformização de Interpretação de Lei do Espírito Santo, foram suscitados dois IRDRs dentro do recorte temporal estabelecido. São os de $n^{\circ}$ 039/2016 e n 040/2016, com mérito já apreciado.

Destaca-se que o acesso à informação dos processos e julgamentos da Turma de Uniformização de Interpretação de Lei do Espírito Santo em IRDR é difícil e insatisfatório. Apesar de haver certa sistematização dos IRDRs e dos 
pedidos de uniformização no endereço eletrônico do órgãol1, o acesso aos acórdãos se restringe à ementa e à súmula de julgamento. Ambos os acórdãos não estão disponíveis na íntegra.12

Em razão da dificuldade encontrada, não é possível fazer análise profunda dos casos, o que também abre discussão acerca da necessidade de tornar as informações de IRDR públicas e amplamente divulgadas para permitir participação e representação adequadas na fixação de tese vinculante.

O IRDR $n^{\circ}$ 039/2016 trata sobre a licitude de tarifas cobradas em contratos de financiamento bancários, sendo conhecido apenas parcialmente e com mérito já julgado.13 O segundo foi o IRDR n 040/2016 admitido e com tese fixada14 sobre a responsabilidade civil da Samarco Mineração S/A pela interrupção no abastecimento de água nas cidades banhadas pelo Rio Doce. Neste caso, houve a fixação de danos morais no valor de mil reais, o que pode ser questionável sobre os limites da matéria julgada. Como se sabe, o IRDR é um instrumento destinado à fixação de teses vinculantes em matéria de direito, ao passo que a reparação civil por danos morais é arbitrada pelo julgador casuisticamente, levando-se em consideração os aspectos individuais de cada litigante e da situação envolvida. Assim, não parece razoável e compatível com o IRDR a fixação prévia de montante indenizável.

Foi o IRDR $n^{\circ}$ 040/2016 que ensejou o Procedimento de Controle Administrativo 0002624-56.2017.2.00.0000 no CNJ para discutir as disposições da

\footnotetext{
$"$ " http://www.tjes.jus.br/institucional/coordenadorias/institucionalcoordenadoriasjuizados-especiaisciveis-e-criminais/decisoes-da-turma-de-uniformizacao/> Acesso em 02 de março de 2020.

12 Apenas O IRDR de $\mathrm{n}^{\circ}$ 0000025-75.2017.8.08.9101 possui inteiro teor disponibilizado, porém com data de julgamento fora do recorte temporal adotado. Com vista à excepcionalidade dos casos em que o IRDR foi julgado pelos órgãos dos Juizados Especiais, outros casos também serão mencionados quando dessa análise.

${ }^{13}$ A tese vinculante fixada foi: "[...] válida a pactuação, nos contratos de financiamento de veículo, do "seguro de proteção financeira", desde que demonstrada a livre opção em sua adesão pelo consumidor, devendo integrar os autos do processo a respectiva apólice. Quanto à cobrança referente a "registro de gravame eletrônico", é ilegítima e abusiva, porquanto cuida-se de custo inerente à atividade da instituição financeira e é medida que vem em seu exclusivo interesse".

${ }_{14}$ Neste IRDR, a tese vinculante é: "a Samarco Mineração é claramente a responsável, devendo responder objetivamente pelos danos causados pela falta de abastecimento de água potável; a responsabilidade é objetiva, podendo as ações serem propostas individualmente, por efeito ricochete; sendo a responsabilidade por danos morais objetiva, quando fixado o valor de $\mathrm{R} \$ 1.000,00$ (um $\mathrm{ml}$ reais), para cada autor postulante da ação".
} 
Resolução do TJES que permitem o julgamento do IRDR por órgãos dos Juizados Especiais, sendo concedida medida liminar pelo Conselheiro Henrique Ávila suspendendo todos os IRDRs em tramitação no Sistema dos Juizados Especiais. O fundamento é de que o TJES estaria esquivando-se de sua competência ao delegá-la aos Juizados Especiais Cíveis, considerando que as disposições do CPC indicam que o órgão responsável para julgamento do IRDR é do Tribunal. Os Juizados Especiais, então, estariam excluídos dessa hipótese, uma vez que eles são órgãos jurisdicionais apartados.

Contudo, pela discussão ainda em fase de maturação, a liminar foi suspensa pelo Plenário do Conselho, a fim de aguardar o pronunciado do STJ e do STF sobre o tema. A liminar foi revogada sob o fundamento de que o CNJ não é competente para dirimir a questão. Em se tratando de atividade jurisdicional, é ato que foge do controle do $\mathrm{CNJ}$.

Apesar disso, o FONAJE apresentou nota técnica no processo em trâmite no CNJ manifestando sobre a possibilidade de julgamento do IRDR pelos órgãos dos Juizados Especiais. Fundamenta tal opinião na impossibilidade do Tribunal em controlar as decisões dos Juizados Especiais, devido à possibilidade de aplicação do juízo de equidade (art. $6^{\circ}$ da Lei n 9.099/95). Em sua manifestação, o FONAJE reconhece a possibilidade de coexistência de duas teses vinculantes em sentidos diferentes em âmbito dos Juizados Especiais e do Tribunal.

Para solucionar o problema, o FONAJE propôs que fosse seguida a orientação do art. $190, \S 7^{\circ}$, do Regimento Interno do TJSP, determinando que o Órgão Especial dirima a divergência. Entretanto, parece claro que essa solução seria ainda uma forma de o Tribunal se imiscuir no julgamento do IRDR quando presente a divergência.

Além do procedimento no CNJ, no IRDR n40/2016 foi formulado pedido de suspensão nacional no STJ, conforme previsão no art. 982, §3․, CPC, tendo em vista existirem quatro IRDRs que tratam sobre o tema no TJMG e no TJES, bem como o ajuizamento de diversas ações de reparação de danos nas varas cíveis e nos Juizados Especiais desses estados. O pedido de suspensão nacional foi feito porque apenas os processos em trâmite perante os Juizados Especiais do Espírito 
Santo estavam suspensos, enquanto os demais continuavam a tramitar, isso em razão da impossibilidade de transposição do IRDR processado nos Juizados Especiais aos processos do Tribunal, gerando "bolha" incomunicável com o restante do sistema de justiça.

O pedido de suspensão nacional será dirigido ao Tribunal competente para julgar o recurso especial ou o recurso extraordinário, STJ ou STF, portanto. Contudo, como o processo foi suscitado a partir de processo de competência dos Juizados Especiais, suas decisões não estão sujeitas a controle por meio de recurso especial, impossibilitando a atuação do STJ nesse caso.

Com base nesses fundamentos, o pedido foi negado pelo STJ, por sua impossibilidade de conhecer possível recurso especial posteriormente. Não houve a pormenorização nesse julgamento do STJ quanto ao cabimento de IRDR no âmbito dos Juizados Especiais, restringindo-se apenas a negar o pedido de suspensão nacional sob este fundamento.

Para além do recorte temporal estabelecido na pesquisa, foram identificados mais dois IRDRs julgados pela Turma de Uniformização de Interpretação de Lei do Espírito Santo em que aqui merecem destaque pontual, tendo em vista a excepcionalidade do caso capixaba. O IRDR $\mathrm{n}^{\circ}$ 000026190.2018.8.08.9101 foi suscitado e inadmitido por decisão monocrática do relator em 20 de julho de 2018, de acordo com as regras internas editadas pelo TJES. Esteve ausente o requisito da efetiva repetição de processos pela falta de demonstração da multiplicidade de demandas com julgamentos diversos. Esse incidente tratava de matéria de origem legislativa estadual, vez que discutia a legalidade da Instrução de Serviço nº 019/2016 do DETRAN/ES.

Já o IRDR nº000025-75.2017.8.08.9101, julgado em 30 de novembro de 2018, foi admitido e teve a tese vinculante fixada.15 Sobre a mesma questão foram manejadas diversas ações individuais e coletivas, sendo fixado o entendimento de

\footnotetext{
${ }^{15}$ Foram duas teses fixadas: "os Juizados Especiais Cíveis são competentes para julgar as demandas relacionadas a bloqueio de internet após a consumação da franquia contratada" e "os danos morais não são presumidos nos casos de bloqueio da internet após o consumo da franquia contratada, dependendo para sua caracterização da efetiva demonstração dos mencionados prejuízos extrapatrimoniais".
} 
que é possível o ajuizamento de ação individual nos Juizados Especiais para garantir a proteção do consumidor coexistindo com a ação coletiva. Em relação aos danos morais, o julgamento se mostrou mais adequado ao determinar que seja feita a análise casuística para identificar a existência de danos extrapatrimoniais, em contraposição com o acórdão do IRDR n 040/2016 que fixou de antemão o valor indenizatório.

\section{CONCLUSÃO}

Os dados obtidos quanto à utilização do IRDR nos Juizados Especiais refletem os debates doutrinários a respeito do tema. Diversos aspectos são controversos em relação aos dois objetos, como a necessidade de ser o incidente suscitado em causa pendente de julgamento no Tribunal e a independência e autonomia dos Juizados Especiais no sistema de justiça brasileiro. A cada posição, uma resposta diferente é encontrada.

Apesar de ser expressiva a repetitividade de demandas nos Juizados Especiais (Koehler, 2014, p. 500), são poucos os casos de suscitação de IRDR nesses processos quando em comparação com os Tribunais. Contudo, isso pode ser mais bem compreendido com o tipo de processo com que os Juizados foram criados para lidar: baixa complexidade e valor econômico. Para tanto, possuem rito que sobrevalorizam a simplicidade e informalidade para alcançar a celeridade, sem que discussões de direito sejam o aspecto central do processo.

É em razão disso que parte da jurisprudência não admite a suscitação de IRDR nos processos dos Juizados Especiais, sendo inviável a incidentalização, além de sugerir a independência e autonomia decisória dos Juizados Especiais. Para estes, os juízes dos Juizados Especiais não estão sujeitos a revisão de decisões pelo Tribunal: existe sistema recursal próprio como conferido pelo art. 98, I, da CF. Assim, o IRDR é compreendido como técnica de causa-piloto, em que o Tribunal também julga o caso além de fixar a tese vinculante.

Por outro lado, parece mais razoável a jurisprudência formada que admite - processamento de IRDR nesses casos, considerando a necessidade de 
uniformização do direito em todos os âmbitos do Poder Judiciário. A doutrina ainda acrescenta diferenças em relação à autonomia dos Juizados Especiais na revisão de seus julgados, o que é justificável em razão de que um processo diferenciado também demanda tratamento diferenciado dos recursos, e à aplicação de precedentes vinculantes de órgãos jurisdicionais superiores.

Assim, quando o IRDR se destina apenas à fixação da tese vinculante pelo Tribunal, à luz da orientação de que o IRDR é mais próximo da técnica de procedimento modelo e não depende de causa pendente de julgamento em segunda instância perante o Tribunal, é o juiz dos Juizados Especiais que irá julgar - caso aplicando ou não o precedente, aproximando-o da técnica de procedimento-modelo, não prejudicando sua competência constitucional. Dessa forma, seria possível harmonizar a uniformização do direito para sua aplicação isonômica e segura em todas as esferas de jurisdição, o que, em última análise, é o objetivo do IRDR pretendido pelo legislador processual.

Sem nenhum posicionamento dominante das Cortes Superiores sobre o tema, a jurisprudência dos Tribunais oscila entre os resultados, enquanto existem órgãos próprios dos Juizados Especiais que aplicam e julgam o IRDR nesse âmbito.

\section{REFERÊNCIAS}

Alvim, J. E. C. (2011). Juizados especiais cíveis: lei 10.259, de 12.07.2001. Curitiba: Juruá.

Cappelletti, M., \& Garth, B. (1998). Acesso à justiça. Tradução de Ellen Gracie Northfleet. Porto Alegre: Fabris.

Cavalcanti, M. A. de. (2016). Incidente de resolução de demandas repetitivas (IRDR). São Paulo: Editora Revista dos Tribunais.

Dinamarco, C. R. (2005). Instituições de direito processual civil. vol. III. 5. ed. São Paulo: Malheiros.

Galanter, M. (2018) Por que "quem tem" sai na frente: especulações sobre os limites da transformação no direito. Tradução de Ana Carolina Chasin. São Paulo: FGV Direito SP. 
Instituto de Pesquisa Econômica Aplicada. (2013). Diagnóstico sobre os Juizados Especiais Cíveis. https://www.ipea.gov.br/portal/index.php?option=com_content\&view=arti cle\&id $=20288$.

Koehler, F. A. L. (2014, novembro). O incidente de resolução de demandas repetitivas e os juizados especiais. Revista de Processo, 39(237), 497-507.

Marinoni, L. G. (2016). Incidente de resolução de demanda repetitiva. São Paulo: Revista dos Tribunais.

Mendes, A. G. C. (2017). Incidente de resolução de demandas repetitivas: sistematização, análise e interpretação do novo instituto processual. Rio de Janeiro: Forense.

Mendes, A. G. C., \& Romano Neto, O. (2015, julho). Análise da Relação entre o Novo Incidente de Resolução de Demandas Repetitivas e o Microssistema dos Juizados Especiais. Revista de Processo, 4O(245), 276-310.

Monnerat, F. V. da F. (2017). O incidente de resolução de demandas repetitivas e os juizados especiais. In B. Dantas et al., Questões relevantes sobre recursos, ações de impugnação e mecanismos de uniformização da jurisprudência. São Paulo: Editora Revista dos Tribunais.

Nery Jr., N., \& Nery, R. M. de A. (2015). Código de processo civil comentado. 15. ed. São Paulo: Editora Revista dos Tribunais.

Oliveira, F. A. (2019). Incidente de Resolução de Demandas Repetitivas: contexto, teoria e aplicação. Belo Horizonte: Editora D`Plácido.

Temer, S. (2017). Incidente de resolução de demandas repetitivas. 2. ed. Salvador: JusPodivm.

Temer, S. (2018). Incidente de resolução de demandas repetitivas. 3. ed. Salvador: JusPodivm.

Watanabe, K. (1985). Filosofia e características básicas do juizado especial de pequenas causas. In K. Watanabe (Org.), Juizado especial de pequenas causas: lei n. 7.244, de 7 de novembro de 1984. São Paulo: Editora Revista dos Tribunais.

Zufelato, C. et al. (2019, novembro). I Relatório de Pesquisa do Observatório Brasileiro de IRDRs. Ribeirão Preto: USP. http://observatorioirdr.direitorp.usp.br.

Zufelato, C., \& Oliveira, F. A. (2020). Perfil dos suscitantes do Incidente de Resolução de Demandas Repetitivas: uma análise empírica. Revista Eletrônica de Direito Processual - REDP, 27(1), 1-30. 
'Camilo Zufelato: Professor Associado de Direito Processual Civil da Faculdade de Direito de Ribeirão Preto da Universidade de São Paulo. Líder e coordenador do grupo de pesquisa Observatório Brasileiro de IRDRs, cadastrado no Diretório Nacional de Grupos de Pesquisa do CNPq. Advogado.

iiGustavo Tavares de Oliveira Borges: Advogado. Membro do grupo de pesquisa Observatório Brasileiro de IRDRs, cadastrado no Diretório Nacional de Grupos de Pesquisa do CNPq..

iiiFernando Antônio Oliveira: Advogado. Mestre em Processo Civil pela Universidade de São Paulo. Membro do grupo de pesquisa Observatório Brasileiro de IRDRs, cadastrado no Diretório Nacional de Grupos de Pesquisa do CNPq.

Data de submissão: 12/03/2020

Data de aprovação: 06/10/2020 